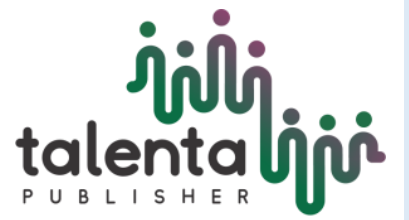

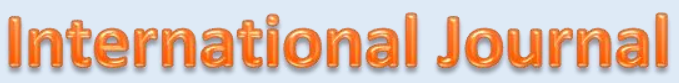 of Ecophysiology
}

\section{The Activities of Plant Extracts Heritage of Melayu Culture-Riau Archipelago on Bacteria Causing Diarrhea}

\author{
Rodesia Mustika Roza ${ }^{1 *}$, Fitmawati ${ }^{1}$, Fenny Irawaty ${ }^{1}$ \\ ${ }^{I}$ Department of Biology, Faculty of Mathematics and Natural Science, University of Riau, Campus Bina \\ Widya Jl. HR Subrantas Panam Pekanbaru, Riau
}

\begin{abstract}
Diarrhea is one of the major health problems in Indonesia. Lingga Malay ethnic in Riau archipelago use alternative medicines in a form of a obat pahit potion to treat diarrhea. This research aimed to determine the antibacterial activity of obat pahit extraction against Escherichia coli ATCC 11775, Salmonella ATCC 14028 and Shigella flexneri ATCC 12022. Antibacterial activity can be seen with the formation of inhibitory zone using diffusion method. The extract concentration used were $100 \%$, $75 \%, 50 \%$ and $25 \%$. Based on the antibacterial activity test, the largest inhibitory zone against E. coli was found at $100 \%$ Cnestis palala extract of $8.29 \mathrm{~mm}$ and the smallest inhibitory zone was found at 25\% traditional medicine practioner (TMP) 2 SP4 of 5.73 $\mathrm{mm}$. The more over, the largest inhibitory zone to S. was found at $100 \%$ Bauhinia semibifida of $8.81 \mathrm{~mm}$; and the smallest inhibitory zone was found at 50\% TMP 2 SP4 of $6.30 \mathrm{~mm}$. Antibacterial activity with the largest inhibitory zone against S. flexneri at $75 \%$ C. palala of $6.21 \mathrm{~mm}$ and the smallest inhibitory zone was found at 50\% TMP 2 SP4 of $5.62 \mathrm{~mm}$
\end{abstract}

Keywords: Bauhinia semibifida, Escherichia coli, Lingga Malay ethnic, Salmonella typhi, Shigella flexneri.

Received 5 November 2018 | Revised 25 December 2018 | Accepted 28 January 2019

\section{Introduction}

Diarrhea is one of the main health problems in developing countries including Indonesia. The disease can last for days and cause dehydration. Severe dehydration lead to weakness, shock and even death, especially in infants and children (Ganong, 1999). Diarrhea occurs due to several factors such as sanitation, nutrition, hygiene, malabsorption, chemical poisoning, allergies, viruses, parasites and bacterial infections (Suharyono, 2008). Bacteria that cause diarrhea are: Staphylococcus aureus, Bacillus cereus, Clostridium perferingens, Escherichia coli,

\footnotetext{
*Corresponding author at: Campus Bina Widya Jl. HR Subrantas Panam Pekanbaru, Riau, Indonesia

E-mail address: rodesiamustikaroza@yahoo.com
} 
Campylobacter jejuni, Klebsiella pnemoniae, Salmonella, Shigella flexneri and Vibrio cholerae (Meliawati ,2009).

In an effort to deal with infection by microorganisms, it requires optimal working power of medicines with minor side effects. Current use of antibiotics is very high, but infection is still one of the global problems due to bacterial resistance to antibiotics. Thus, it is necessary to develop traditional medicines to support the improvement of public health (Ardiansyah, 2002). The World Conservation Monitoring Center reports that the territory of Indonesia is an area with various types of medicinal plants that have been utilized to reach 2,518 species (Galingging and Bhermana, 2010). The knowledge of local people in the use of medicinal plants is different, namely in a simple and complex manner. In simple terms, the community uses one type of plant while in a complex way the community utilizes various medicinal plants or mixed ingredients called herbs to cure various disease complaints (Hanadari, 2014). This herb is made based on ancestral recipes, customs, beliefs, habits and traditional knowledge and experience (Dewoto, 2007). This traditional treatment can still be found in various regions in Indonesia, one of which is known as the Bitter Medicinal Herb / Medicinal Rebus, in Lingga District, Lingga Regency, Riau Islands. Bitter medicine made by Traditional Medicine Practitioners (POT).

Several studies showed that flower of rosella (Hibiscus sabdariffa L.) has inhibitory effect on E. coli (Ryaniarti and Susilo, 2015). Sawitti et al (2013) study bitter leaf extract against E. coli, Dewanti \& Teguh (2011) study the antimicrobial activity of Foliasyzygium polyanthum Wight bay leaf infusions on E. coli in vitro, Bakhriansyah et al activity test of sago root infusion (Metroxylon sagu) against S. typhi. Information about the activity of bitter medicinal herbs and their composition in inhibiting the growth of diarrhea-causing bacteria is unknown. Therefore, it is necessary to conduct a study to test the antibacterial activity of bitter medicinal herbs extract of Lingga Malay culture, single plant Bauhinia semibifida and Cnetis palala in inhibiting the growth of diarrhea-causing bacteria (E. coli ATCC 11775, S. typhi ATCC 14028 and S. flexneri ATCC 12022 ).

\section{Materials and Methods}

This research was carried out by making five extracts, namely three bitter medicinal herbs and two single herbs ((Kangkang Katup (Bauhinia semibifida) and Seven Lapis Root (Cnetis palala). Samples were obtained from Kalan Village, SP4 Village and Linau Village in Lingga District, Regency Lingga, Riau Islands and test bacteria were obtained from the UPT of the Health and Environment Laboratory of the Riau Province Health office.The five samples were made with a decoction extract with concentrations of $100 \%, 75 \%, 50 \%$ and $25 \%$, as a negative control of $100 \mathrm{~mL}$ aquadest and positive control of chloramphenicol $30 \mu \mathrm{g}$ The test bacteria suspension was prepared as much as $10^{8} \mathrm{CFU} / \mathrm{ml}$ Test was carried out on MHA medium Repeated treatment was 3 replications and antibacterial activity of the extract was observed to 
inhibit the growth of diarrhea-causing bacteria through the inhibitory zone formed during incubation for 24 hours.

\section{Plant Extracts Preparation}

Bitter medicine and single herbs (simplicia) as much as $100 \mathrm{~g}$ in $1 \mathrm{~L}$ distilled water (infundation) in a container (cauldron) heated on a bath \pm 15 minutes counted when the water began to boil, carried out for 3 consecutive days, after the first boiling (day 1), the sample is left in the container, to be boiled again on the second and third days (Nurhalimah et al. 2015) The results of the decoction were filtered using filter paper, $200 \mathrm{ml}$ of extract was used and considered as $100 \%$ concentration, dilution was carried out to obtain concentration variations of 100\%, 75\%, 50\% and 25\% (Rahmawati and Siti 2014).

\section{Nutrient Agar (NA) Medium}

This media NA is used to breed bacteria, making it by weighing $20 \mathrm{~g}$ of NA dissolved in $1 \mathrm{~L}$ of distilled water using a stirring rod and heated on a hot plate. Sterilized using an autoclave with a pressure of 15 psi at $121^{\circ} \mathrm{C}$ for 15 minutes (Aswarita 2013).

\section{Mueller Hinton Agar (MHA) Medium}

MHA media was used for testing antibacterial activity, making it with MHA weighing $38 \mathrm{~g}$ dissolved in $1 \mathrm{~L}$ distilled water using a stirring rod and heated on a hot plate. Sterilized using an autoclave with a pressure of $15 \mathrm{psi}$ at $121^{\circ} \mathrm{C}$ for 15 minutes.

\section{Preparation of Test Bacterial Suspension}

The test bacteria were inoculated as much as one ounce into $100 \mathrm{ml}$ MHB from the inclined NA media and incubated $18-24$ hours in a shaker incubator $\left(150 \mathrm{rpm}, 37^{\circ} \mathrm{C}\right)$. The number of bacterial colonies grown in petri dishes was calculated using the total plate count (TPC) method to obtain $108 \mathrm{CFU} / \mathrm{ml}$ colonies (Sutton, 2011)

\section{Antibacterial Activity Test (Disc Diffusion Method)}

Test bacteria (108 CFU / ml) of $1 \mathrm{ml}$ were inoculated into petri dishes, then poured $15 \mathrm{ml}$ of MHA (pour plate) and allowed to solidify (Oktavia et al. 2013). Each extract was dripped on $100 \mu \mathrm{L}$ sterile disc paper, allowed to stand for \pm 15 minutes (Atikah 2013). After condensing media positioned on the surface of the media: herb extracts and medicinal plants with various concentrations $(100 \%, 75 \%, 50 \%$ and $25 \%$ ), sterile distilled water as much as $100 \mu \mathrm{L}$ (negative control) and chloramphenicol $30 \mu \mathrm{g}$ (positive control). After being incubated for 24 hours, antibacterial activity was observed by measuring the diameter of the inhibitory zone (mm) using a calipse.

\section{Data analysis}


Antibacterial activity of bitter medicinal herb extract, B. semibifida and C. palala on the growth of E. coli ATCC 11775, S. typhi ATCC 14028 and S. flexneri ATCC 12022 with data (inhibition zone diameter) obtained were analyzed descriptively, displayed in the form of tables and picture. Antibacterial activity of extracts in the form of inhibitory zones formed in inhibiting the growth of test bacteria was categorized according to Susanto et al. (2012) in Rachmawaty (2016), the diameter of the inhibitory zone was $<5 \mathrm{~mm}$, the activity was categorized as weak, the diameter of the inhibition zone was $6-10 \mathrm{~mm}$ categorized as moderate, the diameter of the inhibition zone was 11-20 mm categorized as strong and the diameter of the inhibitory zone> 21 $\mathrm{mm}$ was categorized as very strong.

\section{Result and Discussion}

In this study to obtain extracts, the infundation method is used, namely the method of extraction of heat using water solvents. In Table 1 it can be seen the average inhibition zone shown by five bitter medicinal herb extracts on three test bacteria that cause diarrhea (E. coli ATCC 11775 , S. ATCC 14028 and S. flexneri ATCC 12022). The largest inhibitory zone for all herb extracts and test bacteria was shown from B. semibifida at $100 \%$ concentration of $8.81 \mathrm{~mm}$ against S. typhi ATCC 14028 and the smallest inhibition zone of $5.62 \mathrm{~mm}$ from POT 2 SP4 ingredients at a concentration of $25 \%$ to S flexneri ATCC 12022. Poeloengan \& Andriani (2013), stated that the inhibition zone diameter was influenced by the absorption capacity of the extract as an antibacterial compound into the agar medium and the sensitivity of the bacteria to the extract. Extracts can inhibit bacterial growth due to the content of secondary metabolites which can act as antibacterial agents because they are able to inhibit bacterial growth Nurhalimah et al. (2015).

Table 1 shows the largest inhibition zone against E. coli ATCC 11775 was shown by $C$. palala extract at a concentration of $100 \%$ which is $8.29 \mathrm{~mm}$ and the smallest inhibition zone of POT 2 SP4 at a concentration of $25 \%$ which is $5.73 \mathrm{~mm}$. Antibacterial activity in the form of inhibitory zones formed in inhibiting the growth of E. coli ATCC 11775 was categorized as moderate and weak based on Susanto et al. (2012) in Rachmawaty (2016). Research by Roslizawaty et al. (2013), from ant nest extract (Myrmecodia sp.) Showing inhibition zone of $6.67 \mathrm{~mm}$. Sawitti et al. ${ }^{9}$, using the sambiloto leaf extract obtained a inhibition zone of 10.063 $\mathrm{mm}$ at a concentration of $100 \%$. The types and composition of plants in these three bitter medicinal herbs can affect the results of antibacterial activity. This is in line with Fitriani et al. (2016), the existence of synergism or antagonism between compounds so that each other increases or decreases the effect in activity.

Table 1. The average of inhibition zone plants extract on bacteria causing diarrhea 


\begin{tabular}{|c|c|c|c|c|}
\hline \multirow[b]{2}{*}{$\begin{array}{l}\text { Plant } \\
\text { extract }\end{array}$} & \multicolumn{4}{|c|}{ Inhibition zone (mm) } \\
\hline & $\begin{array}{c}\text { Concentration } \\
(\%)\end{array}$ & $\begin{array}{c}\text { Escherichia } \\
\text { coli } \\
\text { ATCC } 11775\end{array}$ & $\begin{array}{c}\text { Salmonella typhi } \\
\text { ATCC } 14028\end{array}$ & $\begin{array}{c}\text { Shigella } \\
\text { flexneri } \\
\text { ATCC } 12022\end{array}$ \\
\hline \multirow{4}{*}{$\begin{array}{c}\text { POT } 1 \\
\text { KALAN }\end{array}$} & 100 & $7,28 \pm 0,51$ & $6,53 \pm 0,20$ & - \\
\hline & 75 & $5,76 \pm 0,37$ & $6,58 \pm 0,40$ & - \\
\hline & 50 & $6,13 \pm 0,53$ & $6,43 \pm 0,39$ & $5,66 \pm 0,23$ \\
\hline & 25 & $5,90 \pm 0,28$ & $6,42 \pm 0,35$ & $5,75 \pm 0,55$ \\
\hline \multirow{4}{*}{ POT 2 SP 4} & 100 & $6,57 \pm 0,28$ & $7,44 \pm 0,09$ & $5,76 \pm 0,09$ \\
\hline & 75 & $6,83 \pm 0,31$ & $7,06 \pm 0,32$ & $5,83 \pm 0,00$ \\
\hline & 50 & $6,18 \pm 0,60$ & $6,30 \pm 0,13$ & $5,62 \pm 0,36$ \\
\hline & 25 & $5,73 \pm 0,06$ & $6,31 \pm 0,26$ & $5,63 \pm 0,14$ \\
\hline \multirow{4}{*}{$\begin{array}{c}\text { POT } 3 \\
\text { LINAU }\end{array}$} & 100 & $6,79 \pm 0,09$ & $6,88 \pm 0,13$ & $5,86 \pm 0,44$ \\
\hline & 75 & $6,09 \pm 0,06$ & $6,50 \pm 0,21$ & $5,99 \pm 0,22$ \\
\hline & 50 & $5,78 \pm 0,07$ & $6,27 \pm 0,27$ & - \\
\hline & 25 & - & $6,11 \pm 0,12$ & - \\
\hline \multirow{4}{*}{$\begin{array}{l}\text { Bauhinia } \\
\text { semibifida }\end{array}$} & 100 & $7,83 \pm 0,97$ & $8,81 \pm 1,94$ & $5,80 \pm 0,31$ \\
\hline & 75 & $6,97 \pm 0,46$ & $8,41 \pm 0,64$ & $6,00 \pm 0,79$ \\
\hline & 50 & $7,18 \pm 0,00$ & $7,55 \pm 0,61$ & $5,78 \pm 0,00$ \\
\hline & 25 & $6,82 \pm 0,28$ & $6,18 \pm 0,14$ & $5,91 \pm 0,40$ \\
\hline \multirow{4}{*}{$\begin{array}{l}\text { Cnestis } \\
\text { palala }\end{array}$} & 100 & $8,29 \pm 1,33$ & $7,30 \pm 0,44$ & $6,11 \pm 0,48$ \\
\hline & 75 & $6,22 \pm 0,17$ & $7,24 \pm 0,25$ & $6,21 \pm 0,33$ \\
\hline & 50 & $6,42 \pm 0,43$ & $6,59 \pm 0,34$ & $5,68 \pm 0,33$ \\
\hline & 25 & $6,57 \pm 0,24$ & $6,34 \pm 0,18$ & $5,64 \pm 0,09$ \\
\hline $\begin{array}{l}\text { Positive } \\
\text { control }\end{array}$ & chloramphenicol & $17,03 \pm 0,00$ & $24,76 \pm 0,00$ & $18,7 \pm 0,00$ \\
\hline $\begin{array}{c}\text { Kontrol } \\
\text { negatif }\end{array}$ & distilled water & - & - & - \\
\hline
\end{tabular}

Note: Inhibition zone $<5 \mathrm{~mm}$ (weak level), 6-10 mm (medium), 11-20 mm (strong), >21 mm (very strong).

The antibacterial activity test against S. ATCC 14028 with indications of inhibition zone formation resulted from $B$. Semibifida extract at a concentration of $100 \%$ which is $8.81 \mathrm{~mm}$ which is the largest inhibition zone and the smallest inhibitory zone is shown from the POT 3 Linau herb extract at a concentration of $25 \%$ namely $6.11 \mathrm{~mm}$. Antibacterial activity in the form of inhibitory zones formed in inhibiting the growth of S. typhi ATCC 14028 is included in the moderate category based on Susanto et al. (2012) in Rachmawaty (2016). In Table 1 can be seen for the concentration of $100 \%$ of the four extracts (POT 2 SP4, POT 3 Linau, B. semibifida and C. palala shows the largest inhibition zone compared to other concentrations. Thus it is known that the antibacterial activity is directly proportional to the concentration of extract. with the 
statement of Rahmawati and Siti (2014), that the higher the concentration, the greater the antibacterial activity.On the herb extract of POT 1 Kalan, the largest inhibition zone was obtained from the concentration of $75 \%(6.58 \mathrm{~mm})$ on the other hand at a concentration of $100 \%$ inhibitory zone, namely 6 Based on the antibacterial activity, it was found that extract activity was not directly proportional to the level of concentration. It was thought that the extract did not work stably in inhibiting the growth of $S$. typhi, indicated by the unequal activity between levels of concentration that can be seen from the inhibition zone formed.

Rahmawati's research (2015) using pacing rhizome water (Costus spiralis) on S. typhi ATCC 14028 resulted in inhibition zones of $8.55 \mathrm{~mm}$ at a concentration of $100 \mathrm{mg} / \mathrm{ml}$ by disc diffusion method. Virgianti (2016) in his study obtained inhibitory zone against S. typhi ATCC 14028 by $15.8 \mathrm{~mm}$ at a concentration of $100 \%$ from the leaves of Ashibata water (Angelica keiskei) which is known to contain alkaloids, tannins and phenolics. Puspita's (2013) study showed antibacterial activity in the form of a low inhibitory zone against $S$. typhi with a range of 1-5 mm inhibition zone diameter from black mangrove decoction (Rhizospora mucronata).

The inhibitory test of $S$. flexneri ATCC 12022 was the largest inhibitory zone of C. palala extract at a concentration of $75 \%$ which was $6.21 \mathrm{~mm}$ and the smallest zone was $5.62 \mathrm{~mm}$ from POT 2 SP4 at a concentration of 50\%. At a concentration of $75 \%$ of POT 2 SP4, POT 3 Linau, B. semibifida and C. Palala obtained the largest inhibition zone. This shows the optimum concentration of four extracts in inhibiting the growth of S. flexneri ATCC 12022 is at a concentration of $75 \%$. At a concentration of $100 \%$ found activity was lower than $75 \%$, this was due to the extract in an unstable condition so that the activity was not directly proportional to the concentration of the extract. According to Elifah \& Esty (2010), the diffusion speed of antibacterial compounds, types of antibacterial compounds and concentration can provide a wide range of inhibitory zones at certain times. The extract concentration has not reached optimal concentration to produce antibacterial activity or has not been effective for removing antibacterial compounds. The decoction extract (infundation method) in this study has not been effective in inhibiting the test bacteria because it has not been able to attract plant metabolites properly. This is reinforced by Alam \& Waluyo (2006) using the boiling method of active substances can be taken only 5\%. According to Bakhriansyah et al.(2011), extraction using water solvents can bind polar active substances such as flavonoid compounds. Rheza's research (2015), the antibacterial activity test of the infusion of bacang mango leaves (Mangifera foetida L.) with a concentration of $10 \%-100 \%$ showed no activity against S. flexneri growth.

Test bacteria in this study are Gram negative bacteria, according to Jawetz et al. (2005), these bacteria have three-layered cell walls, namely lipoproteins, phospholipid outer membranes and lipopolysaccharides with lipid content in the cell wall ranging from 11-22\%. Phospholipid outer membranes can cause antibacterial chemical components difficult to penetrate the cell wall of Gram negative bacteria. Different things were found in Gram positive bacteria, where the cell 
wall of this bacterium was single-layered with a lipid content of 1-4\%, making it more likely to inhibit the growth of Gram-positive bacteria compared to Gram-negative bacteria.

The antibacterial activity of each extract is different because of the variation in the number and metabolite of plants in bitter medicine. Hazimi's research (2017), compounds contained in bitter medicinal herbs include: C. palala (flavonoids alkaloids, terpenoids, saponins and tannins), cloves (alkaloids, flavonoids, terpenoids, saponins, tannins and steroids), keteng skin (alkaloids, flavonoids, terpenoids, saponins and tannins), seba leaves (alkaloids, terpenoids, saponins and tannins), edible roots (flavonoids, terpenoids, and tannins), key chains (alkaloids, flavonoids, terpenoids, saponins and tannins), piths of the earth (alkaloids, saponins and tannins), root of layer laughter (alkaloids, flavonoids, terpenoids, saponins and tannins) and B. semibifida (flavonoids, terpenoids, saponins and tannins).

Pepeljnjak et al. (2005) stated that the mechanism of action of flavonoids is to form complexes with extracellular proteins, inactivate enzymes and damage cell membranes. In general, these compounds were able to inhibit the growth of Gram positive and Gram negative bacteria (Cowan 1999). Terpenoids as antibacterials can lyse bacterial cell walls. This compound reacts with porin (transmembrane protein) on the outer wall of bacterial cells, forming a strong polymeric bond which causes damage to the protein. Damage to the porin which is the entrance and exit of the compound will reduce the permeability of the bacterial cell wall so that bacterial cells lack nutrients, as a result bacterial growth is inhibited or dead (Cowan 1999). Alkaloids are able to influence the formation of peptidoglycan in bacterial cells, so that bacterial cells cannot form perfectly and experience death.

Negative control and positive control were used as a comparison in determining antibacterial activity from extracts of bitter and single herbs. Negative control was used by distilled water to see the effect of solvent on the extraction stage on the resulting inhibition zone. Positive control uses chloramphenicol, a broad-spectrum antibiotic. According to Pelczar \& Chan (2008) chloramphenicol is relatively non-toxic when used in mammals therapeutically.

\section{Conclussion}

Based on the research conducted, the following conclusions were obtained:

1. The biggest inhibitory zone against E. coli ATCC 11775 was obtained from C. palala extract which was $8.29 \mathrm{~mm}$ at a concentration of $100 \%$ and the smallest inhibition zone of $5.73 \mathrm{~mm}$ from POT 2 SP4 at a concentration $25 \%$.

2. The biggest inhibitory zone against $S$. typhi ATCC 14028 was obtained from B. semibifida extract which was $8.81 \mathrm{~mm}$ at a concentration of $100 \%$ and the smallest inhibition zone of $6.11 \mathrm{~mm}$ from POT 3 Linau at a concentration of $25 \%$. 
3. The biggest inhibitory zone against S. flexneri ATCC 12022 was obtained from C. palala extract which was $6.21 \mathrm{~mm}$ at a concentration of $75 \%$ and the smallest inhibition zone of 5.62 $\mathrm{mm}$ at a concentration of $50 \%$ of POT $2 \mathrm{SP} 4$

\section{References}

[1] Ardiansyah, L., Nuraida, Andarwulan. Aktivitas antibakteri ekstrak daun beluntas (Pluchea indica Less.). Malang: Prosiding Seminar Tahunan PATPI. 2002.

[2] Alam, S. Waluyo, S. 2006. Sarang Semut Primadona Baru di Papua. Majalah Nirmala. Edisi Juli 2006. Jakarta: PT. Gramedia Pustaka Utama.

[3] Aswarita, R., 2013. Interaksi ekstrak daun lidah buaya (Aloe vera L.) dan daun jambu biji (Psidium guajava L.) terhadap daya hambat Escherichia coli secara in vitro. Jurnal Edubio Tropika 1 (2): 61-210.

[4] Bakhriansyah, M. Aswin, F., Deviyanti, R., 2011. Efek antibakteri in vitro dan antidiare in vivo akar sagu (Metroxyon sagu). Majalah Farmasi Indonesia. Kalimantan: Fakultas Kedokteran, Universitas Lambung Mangkurat 22 (3) 158-165.

[5] Cowan, M,M., 1999. Plant product as antimicrobial agents. Jurnal Microbiology Reviews 12 (4): 564-582.

[6] Dewoto, 2007. Pengembangan obat tradisional indonesia menjadi fitofarmaka. Majalah Kedokteran Indonesia 57; 7 205-211.

[7] Dewanti, S., Teguh, M,W., 2011. Uji aktivitas antimikroba infusum dau salam (Folia syzygiumpolyanthum Wight) terhadap pertumbuhan bakteri Escherichia coli secara in vitro. Jurnal medika planta 1 (4).

[8] Elifah. E. 2010. Uji antibakteri fraksi aktif ekstrak metanol daun senggani (Melastoma candidum, D. Don) terhadap Escherichia coli dan Bacillus substilis serta profil kromatografi lapis tipis [skripsi]. Surakarta: Fakultas Matematika dan Ilmu Pengetahuan Alam, Universitas Negeri Surakarta.

[9] Fitriani, A, Nurdiana, D, Lia, Y,B., 2016. Efek antibakteri sediaan tunggal dan kombinasi air perasan jeruk nipis dan madu terhadap Sterptococcus mutans. Jurnal Kedokteran Gigi 1 (2).

[10] Ganong, W,F., Buku Ajar Fisiologi Kedokteran. Ed ke-17. Jakarta: EGC. 1999. Galingging, R.Y., Bhermana. Perwilayahan Plasma Nutfah Tanaman Obat Berbasis Sistem Informasi dan Geografi di Kalimantan Tengah. Palangkaraya: Balai Pengkajian Teknologi dan Pertanian Kalimantan Tengah. 2010. 
[11] Handari, T., Terapi Top Herbal untuk Ragam Penyakit. Yogyakarta: Dafa Publishing. 2014.

[12] Hazimi, H., 2017. Komposisi tumbuhan pada ramuan "obat pahit" suku Melayu Lingga asal Kepulauan Riau dan skriking fitokimianya [skripsi]. Pekanbaru: Fakultas Matematika dan Ilmu Pengetahuan Alam. Universitas Riau.

[13] Jawetz, Melnick, Adelberg. 2005. Medical microbiologi. Jakarta: Salemba Medica. hlm 353-357.

[14] Melliawati, R, Escherichia coli dalam kehidupan manusia. Biotrends 4;1. 2009. Nurhalimah, H., Novita, W., Tri,D,W., 2015. Efek antidiare ekstrak daun beluntas (Pluchea indica L.) terhadap mencit jantan yang diinduksi bakteri Salmonella typhimurium. Jurnal Pangan dan Agroindustri 3 (3): 1083- 1094.

[15] Oktavia, Gebby, A.E., Muslimin, I., Lisa, L., 2013. Pengaruh pemberian ekstrak biji mahoni (Swietenia mahagoni) terhadap penghambatan pertumbuhan Escherichia coli dengan metode difusi cakram. Lenterabio 3 (3): 239-243.

[16] Pelczar, M,J., Chan, E,C,S., 2008. Dasar-Dasar Mikrobiologi. Jakarta: UI Press. Pepeljnjak, S., Kalodera, Z., Zovko, M., 2005. Antimicrobial activity of flavonoid from Pelargonium rodula (cav.) L'herit. Acta Pharm. 55: 431435.

[17] Permatasari, E,P.P., 2015. Uji aktivitas antibakteri ekstrak etanol dan infusa daun ubi jala merah (Impomoea batatas L mak) terhadap bakteri Streptococcus pyogenes Surakarta: Fakultas Farmasi, Universitas Muhammadiyah Surakarta.

[18] Permatasari, G,A., Besung, I,N,K., Mahatmi, H,. 2013. Daya hambat perasan daun sirsak terhadap pertumbuhan bakteri Escherichia coli. Indonesia Medicus Veterinus 2(2): 162-9.

[19] Poeloengan, M., Andriani. 2013. Kandungan Senyawa Aktif dan Daya Antibakteri Daun Sambung Darah. Jurnal Veteriner. 14 (2): 145-152.

[20] Presly, S.L.S,. 2014. Uji aktivitas antibakteri infusa biji buah langsat (Lansium domesticum Cor.) terhadap Salmonella typhi.Jurnal Mahasiswa PSPD FK Universitas Tanjungpura 1 (1).

[21] Puspita A.A.A.Y.N,. 2013. Uji aktivitas antibakteri ekstrak daun bakau hitam (Rhizopora mucronata) terhadap bakteri penyebab diare [skripsi]. Bogor: Fakultas Perikanan dan Ilmu Kelautan, Institut Petrtaian Bogor.

[22] Rachmawaty, D.U., 2016. Uji aktivitas antibakteri ekstrak etanol, etil asetat dan petroleum eter rambut jagung manis (Zea maysssaccharata Sturt) 
terhadap bakteri Staphylococcus aureus dan Escherichia coli. Malang: Fakultas Sains dan Teknologi, Universitas Islam Negeri Malang.

[23] Ryaniarti, M.M.E.W., Susilo RA. 2015. Uji daya hambat air rebusan bunga rosella (Hibiscus sabdariffa L.) terhadap pertumbuhan bakteri Escherichia coli. Jurnal Wiyata 2;1.

[24] Rahmawati, M., 2015. Uji aktivitas antimikroba ekstrak etanol dan air rimpang pacing (Costus spiralis) terhadap bakteri Escherichia coli, Shigella dysenteriae, Salmonella typhimurium, Bacillus Substilis, Staphylococcus aureus serta fungi Candida albicans. [skripsi]. Jakarta: Fakultas Kedokteran dan Ilmu Kesehatan, Program Studi Farmasi, Universitas Universitas Islam Negeri Syarif Hidayatullah Jakarta.

[25] Rahmawati, F, Siti H.B., 2014. Studi aktivitas antibakteri sari daun binahong (Anredera cordifolia) terhadap pertumbuhan Bacillus cereus dan Salmonella Enteritidis.Unnes Journal of Life Science 3 (2).

[26] Rheza, M. 2015. Uji aktivitas antibakteri infusa daun mangga bacang (Mangifera foetida L.) terhadap pertumbuhan Shigella flexneri. Jurnal Mahasiswa Pspd Fk Untan 3 (1).

[27] Roslizawaty, Nita Y.R., Fakhrurrazi, Herrialfian. 2013. Aktivitas antibakteri ekstrak etanol dan rebusan sarang semut (Myrmecodia sp.) terhadap bakteri Escherichia coli. Jurnal Medika Veterinaria 7 (2).

[28] Sari, P.M., 2013. Aktivitas Ekstrak Kasar Daun Mete (Anacardii folum) dengan pengekstrak etanol $70 \%$ sebagai antibakteri Salmonella typhi [skripsi]. Surakarta: Fakultas Keguruan dan Ilmu Pendidikan. Universitas Muhammadiyah Surakarta.

[29] Sarimole, E., Martanto, M., Haryono, S., Jubhar, C.M., 2014. Pemanfaatan tumbuhan hutan sebagai obat tradisional masyarakat di kampung yenbekwan, distrik mansuar, kabupaten raja ampat. Di dalam: Prosiding Seminar Nasional Raja Ampat. Waisai. 12-13 Agustus 2014. Salatiga: Program Studi Magister Biologi, Universitas Kristen Satya Wacana.

[30] Sawitti, M.Y., Hapsari, M., and Nengah, I.K.B., 2013. Daya hambat perasan daun sambiloto terhadap pertumbuhan bakteri Escherichia coli. Indonesian Medicus Veterinus. Bali: Fakultas Kedokteran Hewan, Universitas Udayana.

[31] Suharyono. Diare akut klinik dan Laboratorik Cetakan Kedua. Jakarta: Rineka Cipta. 2008.

[32] Sutton, S., 2011. Measurement of microbial cells by optical density. Journal of Validation Technology 2001, 46-49. 
[33] Virgianti, D.P., Senia A. 2016. Daya hambat ekstrak air daun Ashitaba (Angeica keiskei) terhadap bakteri Salmonela typhimurium. Di dalam: Prosiding Seminar Nasional dan Diseminasi Penelitian Kesehatan 2016. Tasikmalaya: STIkes Bakti Tunas Husada Tasikmalaya :1-5. 